УДК 004.42:001.895:378.14

DOI:

Олег Маслій, кандидат педагогічних наук, старший науковий співробітник, заступник начальника академії з навчальної роботи, начальник навчального відділу Військової академії, м. Одеса

\title{
МЕТОДИ АКТИВІЗАЦІЇ НАВЧАННЯ В СИСТЕМІ ПРОФЕСІЙНОЇ ПІДГОТОВКИ ОФІЦЕРІВ РАКЕТНО-АРТИЛЕРІЙСЬКОГО ОЗБРОЄННЯ
}

У статті проаналізовано комплекс методів активізації навчання, спрямованих на підтримку індивідуального розвитку майбутніх офіцерів РАО. Подано конкретні приклади практичної реалізації методів активізації за навчальними модулями професійної підготовки у ВЗВО офіџерів РАО. Виявлено, щзо якість підготовки курсантів РАО забезпечується при використанні таких методів активізації, як-от: проблемні лекиії, лекції-візуалізації, лекції-прес-конференції, брифінги, семінари-дискусї, семінари з елементами диспуту, рольової гри, слайд-презентацій, кейс-методу і методу конкретних ситуацій тощяо. Наведені складові організачійно-методичного забезпечення, потрібні для підготовки курсантів РАО до подібного роду занять.

Ключові слова: методи активізації навчання; військовий заклад вищої освіти; офіщер служси ракетноартилерійського озброєння; педагогічна лабораторія; організачійно-методичне забезпечення.

Puc. 1. Лim. 14.

Oleh Masliy, Ph.D.(Pedagogy), Senior Researcher, Deputy of the Head of the Academy of Academic Affairs, Head of the Training Department of the Military Academy, Odesa

\section{LEARNING ACTIVATION METHODS IN THE SYSTEM OF PROFESSIONAL TRAINING OFTHE OFFICERS OF MISSILE AND ARTILLERY ARMAMENT}

The article examines the complex of learning activation methods aimed at promoting individual development of the future officers of missile and artillery armament. It provides specific examples of applying the activation methods through learning modules of professional training in MIHE of the officers of MAA. The activation methods intend to develop mental activities of cadets, their learning and cognitive activities, motivation for professional activities, desire for creativity and transformation.

The quality of the MAA cadets training is revealed to be ensured by applying the following activation methods: problem lectures, visualization lectures, lectures-press-conferences, briefings, discussion workshops, workshops with the elements of debates, role plays, slides-presentations, using a case-method and a case-study, etc.

The problem lectures are revealed to be the most efficient at the end of learning modules, when summarizing the material, its systematization, using the cadets' knowledge and skills gained not only through the material of certain learning module, but also due to their previous experience. However, a lecture-visualization may be delivered in any part of the module; and a briefing, as an introductory lesson (a lesson of questions and answers), should be given before teaching a broad subject; and after that the discussion workshops are conducted, where the learning material should be given as case-studies which improve the MAA cadets' active cognitive activities and their skills to find innovative solutions while solving non-standard problems in unpredictable situations. The article provides the examples of a problem lecture from the learning module "Construction and Operation of the Artillery Devices", visualization lecture from the learning module "Optical Characteristics of the Artillery Devices", a briefing from the subject "The Overview of the Construction of the Artillery Guns" of the learning module "Fundamentals of Missile and Artillery Armament and Maintenance Means".

The components of organizational and methodological support are given (pedagogical laboratory) which are necessary for training MAA cadets for typical lessons of every learning subject.

Keywords: learning activation methods; military institution of higher education; an officer of missile and artillery armament; a pedagogical laboratory; an organizational and methodological support.

П остановка проблеми. Стратегічний курс держави на інтеграцію в ЄС і НАТО, закріплений в Конституції України, потреба у формуванні безпекового середовища в сучасних умовах тривалого збройного конфлікту на сході України поставили перед вищою військовою школою найважливішу проблему організації ефективної підготовки військових фахівців для Збройних Сил України, зокрема офіцерів служби ракетно-артилерійського озброєння (PAO). Поява в останні роки принципово нових систем озбросння і способів бойових дій також зумовлює діалектичну зміну пріоритетів у професійній підготовці майбугніх офіцерів РАО. Сучасне оновлення характеру діяльності випускників вищих військових 


\section{МЕТОДИ АКТИВІЗАЦЇ̈ НАВЧАННЯ ВСИСТЕМІ ПРОФЕСІЙНОӤ ПДГОТОВКИ ОФІЦЕРІВ РАКЕТНО-АРТИЛЕРІЙСЬКОГО ОЗБРОЄННЯ}

навчальних закладів вимагає зосередження зусиль на підвищених вимогах до якості їхньої професійної підготовки, рівня їхньої професійної компетентності. Така підготовка повинна забезпечувати перехід від відтворення нових знань до активного і самостійного їх засвоєння, орієнтування на розвиток творчих здібностей i тактичного мислення майбутніх офіцерів, формування в них умінь і навичок всебічно аналізувати обстановку і приймати оптимальні рішення в будь-яких непередбачуваних умовах. Організація такої підготовки потребує передусім упровадження нових методів активізації навчання та відповідного методичного забезпечення, його розробки і критичного аналізу за критеріями якості навчання у військових закладах вищої освіти (ВЗВО). Отже, розв'язання науково-методичних питань підготовки до майбутньої професійної діяльності офіцерів РАО, пошук інноваційних форм, методів, методик і технологій активізації їх навчання у ВЗВО, створення комплексного організаційно-методичного забезпечення професійної підготовки офіцерів ракетноартилерійського озброєння виступає одним із важливих завдань військової освіти України.

Аналіз останніх досліджень і публікацій. Проблемам дослідження інноваційних форм, методів, методик і технологій активізації навчання у вищій школі, формування організаційнометодичного забезпечення професійної підготовки майбутніх фахівців, організації їхньої активної самостійної навчальної діяльності 3 метою підвищення якості навчання присвячено багатопраць науковців (В. Беспалька [1], С. Виговської [2], Р. Горбатюка, I. Зязюна [5], I. Луцик [7], О. Проценка [11] та ін.), зокрема у вищій військовій школі (М. Бутника [8], С. Дякова [4], М. Нещадима [10], Ю. Приходька, І. Толока [13], В. Ягупова [14] та ін.).

Проте питання впровадження інноваційних методів активізації навчання упроцес професійної підготовки офіцерів ракетно-артилерійського озброєння та створення комплексу відповідного організаційно-методичного забезпечення означеної підготовки і практичної перевірки цього комплексу в навчальному процесі В3ВО ще окремо не досліджувались.

Мета і завдання статті. Метою і основним завданням статті $є$ дослідження й аналіз на основі практичної реалізації в навчальному процесі комплексу методів активізації навчання та їх організаційно-методичного забезпечення як важливої складової професійної підготовки у ВЗВО офіцерів служби ракетно-артилерійського озброєння.
Виклад основного матеріалу дослідження. Методи активізації навчальної діяльності в системі організаційно-методичного забезпечення професійної підготовки майбутніх офіцерів, на думку вчених, є важливою структурною складовою педагогічної системи ВЗВО $[10,455,458]$, а організаційно-методичне забезпечення означеної підготовки загалом “забезпечує інтеграцію міжпредметних зв’язків і визначає форми, методи й засоби методичної діяльності науково-педагогічного складу щодо організації, забезпечення та корегування навчальної діяльності майбутніх офіцерів" [4, 54].

Впровадження комплексу методів активізації навчання та реалізація відповідного організаційнометодичного забезпечення професійної підготовки майбутніх офіцерів РАО в освітньому процесі Військової академії (м. Одеса) здійснювались протягом шести років (2012 - 2018 рр.).

3 урахуванням висновків, зроблених під час тривалого (лонгітюдного) дослідження, було розроблено алгоритм реалізації авторської концепції на практиці: проводилися відкриті заняття, методичні наради науково-педагогічних працівників з обміну досвідом, самоатестація науково-педагогічних працівників, спроектовано авторські курси з дисциплін військово-професійної і професійно-спеціальної підготовки, електронні навчально-методичні комплекси, методичні посібники тощо.

У процесі професійної підготовки майбутніх офіцерів РАО використовувалися традиційні (фронтальні, групові, індивідуальні) методи навчання та інноваційні методи активізації (рис. 1).

Методи активізації були зорієнтовані на розвиток розумової діяльності курсантів, їх навчальної та навчально-пізнавальної активності, мотивів у службово-професійній діяльності, прагнення до творчості і перетворень. 3 огляду на це, в освітньому процесі підготовки майбутніх офіцерів РАО проводились заняття за відповідними формами, що сприяло їх активізації, й, відповідно, підготовленості.

Лекції, як основний вид навчальних занять у В3ВО та різновид навчально-методичних матеріалів, призначені для викладання теоретичного матеріалу і складають основу наукових знань курсантів, формують їх світогляд, розкривають фундаментальні питання, сприяють розвитку творчих здібностей майбутніх офіцерів. Вони (лекції) $€$ логічно злагодженим, систематично послідовним і якісним викладанням навчального матеріалу та повинні визначати напрям, основний зміст усіх інших видів занять, а також самостійної роботи курсантів [8, 91 - 93]. 


\section{МЕТОДИ АКТИВІЗАЦЇ̈ НАВЧАННЯ В СИСТЕМІ ПРОФЕСІЙНОЇ ПІДОТОВКИ ОФІЦЕРІВ РАКЕТНО-АРТИЛЕРІЙСЬКОГООЗБРОЕННЯ}

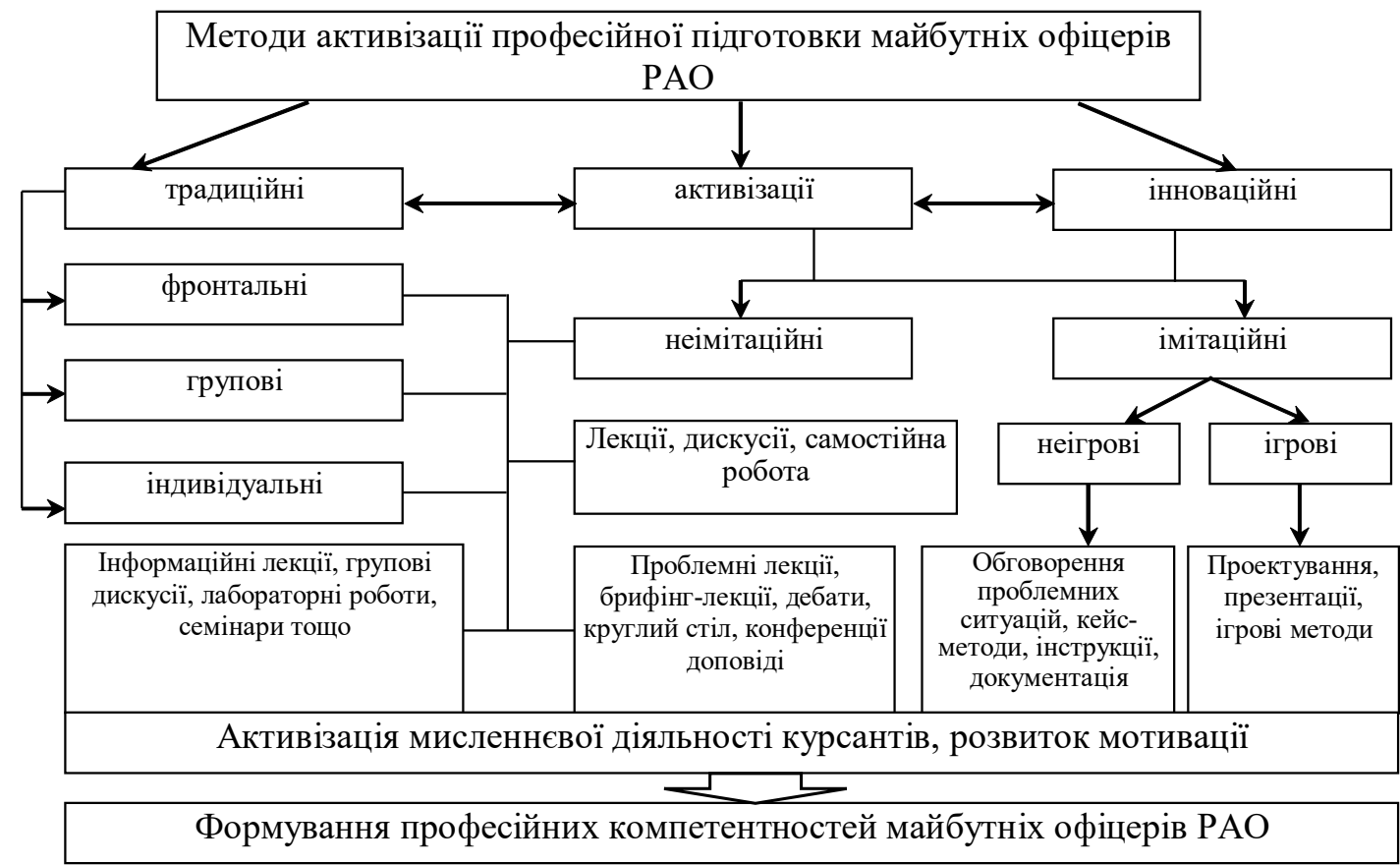

Рис. 1. Структура методів активізації професійної підготовки майбутніх офіцерів РАО

Отже, лекційні заняття, як традиційні, так і інноваційні, що сприяють активізації процесу навчання майбутніх офіцерів РАО, як-от: проблемні лекції, лекції-візуалізації, лекції -пресконференції, брифінги тощо, повинні носити орієнтований характер, спрямований на формування базових знань відповідно до стандартів вищої освіти України галузі знань “Воєнні науки, національна безпека, безпека державного кордону”, спеціальності “Озброєння та військова техніка".

На відміну від традиційної лекції, на якій подається і пояснюється готова інформація, що підлягає запам'ятовуванню, на проблемній лекції нове знання вводиться як невідоме, що необхідно “відкрити”. Завдання науково-педагогічного працівника - створити проблемну ситуацію i спонукати курсантів до пошуку вирішення проблеми, крок за кроком підводячи їх до визначеної мети. Для цього новий теоретичний матеріал необхідно представити у формі проблемного завдання, в умові якого повинні бути суперечності, які необхідно виявити і вирішити [12].

Часто на початку проблемної лекції використовується інтелектуальна розминка, в основній частині - діалогічне спілкування, а наприкінці - бліц-опитування. Під час такої лекції необхідно окремо розглянути принципи можливої науково-дослідницької або самостійної роботи курсантів 3 даної теми, пробудити інтерес і самостійність думки [2, 313 - 314].
Так, 3 метою активізації навчальної діяльності майбутніх офіцерів РАО було розроблено “контент-конспекти” (робочі зошити), які використовувались за такої форми викладу інформації, що наближало процес навчання до пошукової, дослідницької діяльності, розвивало в майбутніх офіцерів РАО теоретичне мислення, пізнавальний інтерес до змісту предмета, професійну мотивацію тощо.

Проте слід зазначити, що, на думку багатьох науковців, незважаючи на позитивні особливості проблемної лекції, зводити всі форми і методи навчання до проблемних не раціонально, адже проблемне навчання вимагає набагато більше тимчасових і матеріальних витрат. Крім того, на нашу думку, такі лекції будуть найбільш ефективними наприкінці навчальних модулів, коли проводяться узагальнюючі та систематизуючі заняття, на яких використовуються набуті курсантами знання і навички не тільки за матеріалом цього навчального модуля, а й 3 урахуванням їхнього попереднього досвіду.

Наприклад, при проведенні проблемних лекцій 3 навчального модуля "Будова та експлуатація артилерійських приладів" викладач обов'язково зазначає, що експлуатація артилерійського озброєння здійснюється в умовах ведення операції об'єднаних сил (АТО) в різний час доби і року, що сучасне артилерійське озброєння характеризується високою бойовою ефективністю, яка забезпечується наявністю в його складі оптичних і механічних 


\section{МЕТОДИ АКТИВІЗАЦЇ НАВЧАННЯ ВСИСТЕМІ ПРОФЕСІЙНОӤ ПІГОТОВКИ ОФІЦЕРІВ РАКЕТНО-АРТИЛЕРІЙСЬКОГО ОЗБРОЄННЯ}

пристроїв, радіоелектронної апаратури і оптикоелектронних механізмів та інших складних пристроїв, що артилерійські прилади, збагачені сучасними досягненнями науки і техніки, стали одним із головних засобів озброєння. На цій основі викладач визначає проблеми, які пов'язані зі значним підвищенням вартості одного пострілу, внаслідок чого основним параметром ефективності артилерійського вогню став критерій “ПОСТРІЛЦІЛЬ”; пропонує визначити і проаналізувати, на чому базується виконання даного критерію.

Крім того, викладач зазначає, що в артилерійських підрозділах і частинах, керованих і самокерованих на кінцевій ділянці траєкторії боєприпасів, змінилися погляди на методи ведення бойових дій. Це стосується як артилерійських підрозділів та частин, так і загальновійськових (танкових) частин. Викладач підводить курсантів до висновку, що в основі системи керування боєприпасами лежать ті ж самі фізичні основи, що і в конструкції артилерійських приладів, виходячи з чого, знання фізичних принципів побудови артилерійських приладів дозволяє командирам усіх ступенів і спеціалістам артилерійського озброєння майстерно застосовувати свої знання на практиці, а від цього значною мірою залежить хід і кінцевий наслідок бойових дій взагалі, адже сучасний бій $\epsilon$ боротьбою розуму та інтелекту, тому перемога буде отримана тією стороною, яка найбільш повно використовує властивості та можливості озброєння. Все це потребує від сучасних артилерійських командирів та інженерів глибоких теоретичних знань і твердих практичних навичок щодо експлуатації та ремонту озброєння з метою підтримання його у стані постійної готовності до бойового використання.

Отже, успіх досягнення мети проблемної лекції забезпечується взаємодією науково-педагогічних працівників і курсантів. Тому основне завдання лектора полягає не тільки в передачі інформації, а в залученні курсантів до осмислення i, можливо, часткового розв'язання об'єктивних суперечностей розвитку наукового знання i способів їх вирішення. Це формує мислення майбутніх офіцерів РАО, викликає пізнавальну активність. У співпраці з викладачем курсанти набувають нові знання, осягають теоретичні особливості своєї професії.

Лекція-візуалізація являє собою усну інформацію, перетворену у візуальну форму. Вона компактна, що дає змогу науково-педагогічним працівникам створювати демонстраційні матеріали та форми наочності, які не тільки доповнюють словесну інформацію, але самі $€$ носіями змістовної інформації. Залежно від навчального матеріалу використовуються різні форми наочності: образотворчі (слайди, малюнки, фото); символічні (схеми, таблиці). На візуалізованій лекції застосовується пояснювально-ілюстрований метод $з$ елементами бесіди (діалоговий метод), що надає їй доступності i наочності. Перевагами таких лекцій $є$ інформаційна цінність, виховний аспект, активність обох сторін, досягнення дидактичних цілей. Читання такої лекції зводиться до вільного, розгорнутого коментування підготовлених візуальних матеріалів, які повинні забезпечити: систематизацію наявних знань; засвоєння нової інформації; створення і вирішення проблемних ситуацій; демонстацію різних способів візуалізації (презентації, електроні книги, 3D-моделі, відеофільми) [3,60 - 61; 6].

Наприкінці лекції-візуалізації викладач зобов'язаний проводити аналіз відповідей, як відображення досягнутого рівня підготовки за даною темою майбутніх офіцерів $\mathrm{PAO}$, а також їхнього зацікавлення щодо змісту навчального модуля. Отже, лекцію-візуалізацію можна проводити у будь-якій частині начального модуля.

Лекція-брифінг може використовуватися і в повному обсязі лекційного часу, на одному або декількох заняттях, і як частина традиційної лекції (наприклад, півпари); дискусії можуть бути продовжені на семінарах, але в ускладненій формі, (наприклад, можна використовувати роботу в групах, застосовуючи підготовлені кейси); може також бути розроблений авторський лекційний курс у будь-якій зі згаданих форм $[11,65]$.

Таку лекцію можна використовувати перед вивченням об'ємної теми, яка посильна для самостійного прочитання і в той же час є важливою для вивчення. Брифінг - це вступне заняття (заняття питань і відповідей), яке можна запропонувати перед вивченням, наприклад, теми “Теоретичні основи побудови ракетних комплексів” (навчальний модуль “Основи побудови ракетно-артилерійського озброєння та ремонтних засобів”). Метою даного заняття є стимулювання майбутніх офіцерів РАО до самостійного вивчення зазначеної теми, розвиток навичок творчої пошукової роботи.

Наприклад, орієнтовна структура заняття 3 навчального модуля “Ракетні комплекси" передбачає визначену науковцями загальну послідовність: вступне слово викладача про мету і порядок проведення брифінгу; роботу асистентів, в якості яких виступають найбільш підготовлені курсанти; інформацію і пояснення викладача шодо теоретичних основ побудови ракетних 


\section{МЕТОДИ АКТИВІЗАЦІЇ НАВЧАННЯ ВСИСТЕМІ ПРОФЕСЙНОӤ ПДГОТОВКИ ОФІЦЕРІВ РАКЕТНО-АРТИЛЕРІЙСЬКОГООЗБРОЄННЯ}

комплексів 3 використанням електронної презентації; роботу в групах під час обговорення проблем; виступ представника від групи курсантів; підведення підсумків.

Застосовуючи інформаційний прийом, викладач пояснює особливості побудови ракетних комплексів, здійснює їх порівняльний аналіз. Далі асистенти (з найбільш підготовлених курсантів) відкривають брифінг, зачитуючи питання. На питання, зазвичай, відповідає лектор, іноді курсанти, які готові вступити в дискусію. Асистенти можуть виступати також як експерти, підводити підсумки 3 наступних позицій: які проблеми побачили учасники, які цікаві ідеї висловили, які труднощі були в обговоренні.

Головне завдання лекції-брифінгу - пробудити інтерес у курсантів до читання, самопошуку тощо. Невимушена обстановка на занятті сприяє вільному обміну думками. На лекції-брифінгу приховано "хитрий” психологічний прийом: недбайливий курсант, що не готовий до заняття, i який не володіє інформацією, в кінцевому підсумку (нехай із запізненням), починає проявляти інтерес, а згодом перебудовується $з$ пасивного споглядача на активного учасника. Така форма проведення занять стимулює творчу пошукову діяльність курсантів, а дебати, як елемент лекції, оживляють iii й активізують майбутніх офіцерів РАО, вчать їх працювати в команді, вести діалог, прислухатися до думки інших, адекватно реагувати на зауваження, формують і розвивають професійні та особистісні компетенції, необхідні сучасним військовим фахівцям.

Наприклад, при проведенні лекції-брифінгу 3 теми “Загальні відомості про будову артилерійських гармат" навчального модуля “Основи побудови ракетно-артилерійського озброєння та ремонтних засобів" викладач спочатку розкриває навчальний матеріал; надає характеристику сучасних гармат, їх класифікацію залежно від типу, призначення, конструкції польоту снаряда, способу пересування тощо; зазначає, що кожна гармата призначена для виконання тих чи інших завдань і має певні властивості, які характеризують удосконаленість та можливості гармати. Перелік усіх властивостей, які повинна мати гармата, складають тактико-технічні вимоги (ТTВ) до конструкції гармати. Вимоги відображають досвід експлуатації подібних зразків озброєння i, в першу чергу, бойовий досвід, стан військової науки і техніки та характер сучасних війн.

Після викладу навчального матеріалу викладач для проведення брифінгу представляє питання дискусійного характеру, як-от:
1. Чим відрізняється самохідна гармата від танка?

2. У чому полягають основні відмінності гармати від реактивної системи залпового вогню?

3. Що таке "калібр" та як він вимірюється?

4. Коли в Україні з'явилися перші гармати і 3 чим це пов'язано?

5. Чим відрізняється “кут прицілу” від “кута підвищення"?

Питання, які під час дискусії залишилися не вирішеними або недостатньо вирішеними, можна перенести на наступний семінар або/та самостійне заняття.

Вагоме значення у комплексі методів активізації навчальної підготовки майбутніх офіцерів РАО мають семінари-дискусії, які не тільки розширюють і поглиблюють теоретичний лекційний матеріал, а, перш за все, припускають спільну участь (діалоговий метод) в обговоренні та вирішенні теоретичних і практичних проблем [7, 128].

Отже, після проведеної лекції-брифінгу дискусію з даної теми пропонується продовжити на семінарі. Навчальний матеріал при цьому слід подавати курсантам у вигляді проблем (кейсів), як один із найбільш ефективних і поширених методів організації активної пізнавальної діяльності майбутніх офіцерів РАО, який зазвичай використовують для вироблення нестандартних рішень під час вирішення нестандартних завдань в умовах непередбачуваних ситуацій.

Технологічний алгоритм проведення таких занять передбачає поділ групи на три підгрупи, кожна 3 яких отримує свій кейс, що містить проблемну ситуацію. Курсантам необхідно знайти рішення, проаналізувавши наявний в кейсі теоретичний матеріал із заданої теми, використовуючи свій життєвий досвід, а також професійні знання. Протягом 15 хвилин у підгрупах обговорюються формулювання, особливості побудови певного обладнання (наприклад, ракетних комплексів), відзначаються технологічні характеристики їх обслуговування та експлуатації. Після обговорення представник кожної підгрупи знайомить учасників дискусії з алгоритмом вирішення кейсу та аргументує прийняте підгрупою рішення. Курсанти з інших підгруп можуть задавати питання, а викладач лише спрямовує обговорення в потрібне русло. Після виконаної групової роботи викладач узагальнює отримані результати [14].

Кейс-метод метод може успішно застосовуватися викладачами дисциплін військово-професійної та професійно-спеціальної підготовки з метою формування військово-професійних компетентностей. 


\section{МЕТОДИ АКТИВІЗАЦІЇ НАВЧАННЯ ВСИСТЕМІ ПРОФЕСІЙНОӤ ПДГОТОВКИ ОФІЦЕРІВ РАКЕТНО-АРТИЛЕРІЙСЬКОГО ОЗБРОЄННЯ}

Крім цього, упідготовці майбутніх офіцерів РАО можна використовувати метод аналізу конкретної ситуації (письмовий або усний), який розвиває аналітичні здібності курсантів, сприяє правильному використанню наявної інформації, вмінню виробляти самостійність та ініціативність у вирішенні задач, висувати нові ідеї, стимулює курсантів до наукової діяльності, підсилює їх прагнення до придбання теоретичних знань 3 метою отримання відповідей на поставлені запитання. Важливо, що дискусії зазвичай мають більш сильні післядії у формі пошукової або пізнавальної активності за рахунок емоційного поштовху.

Предметом дискусії можуть бути не тільки суто військові проблеми, а й моральні, а також міжособистісні відносини курсантів. Результати таких дискусій набагато сильніше модифікують поведінку людини, ніж просте засвоєння моральних норм на рівні знання [9, 339 - 340]. Отже, дискусійні методи активізації виступають як засіб не тільки навчання, а й виховання, що особливо важливо для підготовки майбутніх офіцерів РАО.

Методами активізації навчання i, відповідно, важливою складовою організаційно-методичного забезпечення $\epsilon$ проведення семінарів у вигляді диспуту, рольової гри, слайд-презентацій тощо. На них обговорюються основні проблеми, висвітлені на лекціях і сформульовані в завданнях на самостійну підготовку. В ході таких семінарів курсанти отримують не тільки знання, а й вміння аналізувати ситуацію, висловлювати i відстоювати власну думку, набувають особистісні та комунікативні компетенції: терпимість і взаємодопомогу, лідерські здібності, повагу поглядів колег, вільне вираження власної позиції і бажання прислухатися до думки інших.

В основу методичного забезпечення активних форм практичних занять покладено принцип організації творчої самостійної роботи 3 елементами нарощування труднощів i проблемності завдань, зокрема тренінги, метою яких $€$ опанування ефективними методиками міжособистісної взаємодії майбутніх офіцерів РАО в різних ситуаціях. Пропонується безліч імітаційних вправ, завдань, проводиться самотестування 3 окремих тем. Технології активного діяльнісно-творчого характеру, що наповнюють зміст таких занять, спрямовані на підтримку індивідуального розвитку курсантів, на надання необхідного простору для прийняття самостійних рішень, вибору змісту і способів навчання, поведінки, розвивають у майбутніх офіцерів РАО творчість, діалогічність, професійну компетентність.
Для узагальнення поданих методичних матеріалів 3 метою активізації аудиторної і позанавчальної діяльності майбугніх офіцерів РАО в контексті впровадження інноваційних педагогічних технологій в освітній процес ВЗВО можна запропонувати створену у Військовій академії так звану “педагогічну лабораторію” $[1 ; 5,127-128]$, в яку відкрито доступ усім курсантам для підготовки до подібного роду семінарських і практичних занять, і яка стосовно кожної навчальної дисципліни містить наступні елементи:

1. Робочу програму навчальної дисципліни.

2. Бібліотеку 3 навчальної дисципліни (навчальна література, монографії, статті, спеціальна література, електроні підручники).

3. Тематичні папки за темами занять (вирізки 3 газет, виписки 3 проблем, конспекти лекцій, доповіді, вправи, тестові завдання та ін.).

4. Папку з організації самостійної роботи по модулю.

5. Оформлене портфоліо 3 навчальної дисципліни: електронний навчальний комплекс, слайд-презентації до лекцій, відеозапис навчальних занять, відомості про викладача i висновок про його роботу, наявність сертифікатів, що підтверджують рівень освіти, кваліфікацію і спеціалізацію викладача, відображення професійного шляху, поглядів і планів педагога.

6. Спецкурси суміжних дисциплін.

7. Матеріали для проведення проблемних занять і круглих столів з актуальних тем та окремих питань навчальної дисципліни.

8. Матеріали для психологічного тестування майбутніх офіцерів РАО з метою диференціації та виділення курсантів за здібностями і мотивацією, визначення професійних якостей на основі самоаналізу та самооцінки, їх подальший розвиток.

9. Матеріали для стимулювання науководослідницької діяльності курсантів, активізації їхньої участі в науково-практичних конференціях.

Висновки. Проаналізовано комплекс методів активізації навчання, спрямованих на підтримку індивідуального розвитку курсантів РАО, підвищення якості їхньої професійної підготовки, як-от: проблемні лекції, лекції-візуалізації, лекції прес-конференції, брифінги, семінари-дискусії, семінари $з$ елементами диспуту, рольової гри, слайд-презентацій, з використанням кейс-методу і методу конкретних ситуацій тощо. Подано конкретні приклади їх практичної реалізації за навчальними модулями професійної підготовки у ВЗВО майбутніх офіцерів служби ракетноартилерійського озброєння. Наведені складові 


\section{МЕТОДИ АКТИВІЗАЦЇ̈ НАВЧАННЯ ВСИСТЕМІ ПРОФЕСІЙНОӤ ПІДГОТОВКИ ОФІЦЕРІВ РАКЕТНО-АРТИЛЕРІЙСЬКОГО ОЗБРОЄННЯ}

організаційно-методичного забезпечення (педагогічної лабораторії), потрібні для підготовки курсантів РАО до подібного роду занять стосовно кожної навчальної дисципліни.

Перспективи подальших досліджень у даному напрямку вбачаються в обгрунтуванні нових методів активізації навчання і виховання та їх практичної реалізації при підготовці майбутніх офіцерів ЗС України за іншими спеціальностями і спеціалізаціями.

\section{ЛІТЕРАТУРА}

1. Беспалько В. П. Образование и обучение с участием компьютера (педагогика третьего тысячелетия). Москва. Воронеж. 2002. 352 с.

2. Виговська С. В., Журба О. Р. Застосування методу проблемної лекції з метою активізації навчально-пізнавальної діяльності студентів. Збірник наукових праць Херсонського державного університету. Педагогічні науки. 2015. Вип. 67. С. 311-315. URL : http://nbuv.gov.ua/ UJRN/znppn_2015_67_58 (дата звернення: 23.04.2019).

3. Деркач Т., Деркач О. Лекція-візуалізація як форма активізації пізнавальної діяльності студентів коледжу. Освіта. Технікуми, коледжі. № 3, 4 (41). 2016. С. 59-62.

4. Дяков С. Обгрунтування систем методичного забезпечення підготовки майбутніх офіцерів інженерних військ до професійної діяльності. Вісник Національної академї Державної прикордонної служби Украӥни. Педагогічні науки. 2009. Вип. 2. С. 52-57.

5. Зязюн І. А. Краса педагогічної дії : навч. посіб. для вчителів, аспірантів, студентів середніх та вищих навчальних закладів / І. А. Зязюн, Г. М. Сагач. К., 1997. 302 с.

6. Караван Ю. В., Саницька А. О., Ташак М. С. Нетрадиційні форми лекцій у вищій школі. URL : http://nauka.zinet.info/15/karavan.php (дата звернення: 23.04.2019).

7. Луцик I. Інтерактивні семінари як форма активізації навчально-пізнавальної діяльності студентів вищих закладів освіти. Наукові записки Тернопільського національного педагогічного університету імені Володимира Гнатюка. Серія : Педагогіка. 2009. № 3. С. 125130. URL : http://nbuv.gov.ua/UJRN/NZTNPU ped 2009 $3 \quad 31$ (дата звернення: 29.04.2019).

8. Методична робота у вищому військовому навчальному закладі: навчально-методичний посібник / М. А. Бутник, В. Г. Головань, М. О. Дроздов, В. О. Ройлян. Одеса : Військова академія. 2015. 198 с

9. Мокрогуз О. П. Мультимедійна презентація в системі засобів навчання. Комп'ютер у школі та сім'ї. 2009. № 8. С. 21-23.

10. Нещадим М. І. Військова освіта України: історія, теорія, методологія, практика : монографія. Київ, 2003. 852 с.

11. Проценко О. Б. Інноваційні лекції у професійній підготовці магістрів. Педагогічний процес: теорія і практика. 2015. Вип. 5-6. C. 63-67. URL: http://nbuv.gov.ua/UJRN/ pptp $2015 \quad 5-6 \quad 14$ (дата звернення: 26.04.2019).

12. Проблемна лекція. URL : https:// pidruchniki.com/10990214/pedagogika/ problemna_lektsiya (дата звернення: 22.04.2019).

13. Толок І. В., Приходько Ю.І. Підготовка військових фахівців з вищою освітою: інноваційні підходи. Педагогічні науки: теорія, історія, інноваційні технології. 2013. № 6. С. 259-269.

14. Ягупов В. В. Нетрадиційні семінарські (практичні) заняття. Семінар-дискусія. URL : https://eduknigi.com/ped_view.php?id=209 (дата звернення: 29.04.2019).

\section{REFERENCES}

1. Bespalko, V.P. (2002). Obrazovaniie $i$ obucheniie s uchastiiem kompiutera (pedagogika tretiego tysiacheletiia) [Education and Teaching by Means of Computer (Pedagogy of the Third Century)]. Moscov, 352 p. [in Russian].

2. Vyhovska, S.V. \& Zhurba, O.P. (2015). Zastosuvannia metodu problemnoi lektsii z metoiu aktyvizatsii navchalno-piznavalnoi diialnosti studentiv [Problem Lecture as a Method of Intensifying the Teaching and Learning Activities of Students]. Scientific Proceedings of Kherson State University. Pedagogical Sciences. Vol.67, pp.311315. [in Ukrainian].

3. Derkach,T. \& Derkach, O. (2016). Lektsiiavizualizatsiia yak forma aktyvizatsii piznavalnoi diialnosti studentiv koledzhu [Lecture-visualization as a Form of Activating Cognitive Activity of the College Students]. Education. Schools, colleges. No. 3, 4 (41). pp. 59-62. [in Ukrainian].

4. Diakov, S. (2009). Obhruntuvannia system metodychnoho zabezpechennia pidhotovky maibutnikh ofitseriv inzhenernykh viisk do profesiinoi diialnosti [The Fundamentals of the Systems of Methodological Support of Training Future Engineer Officers to Their Professional Activities]. Magazine of National Academy of the State Border Guard Service of Ukraine. Pedagogical Sciences. Vol 2. pp.52-57. [in Ukrainian].

5. Ziaziun, I.A. (1997). Krasa pedahohichnoi dii: navch.posib. dlia vchyteliv, aspirantiv, studentiv serednikh ta vyschykh navchalnykh zaklasiv [Beauty of Pedagogical Activity: Textbook 


\section{МЕТОДИ АКТИВІЗАЦЇ НАВЧАННЯ В СИСТЕМІ ПРОФЕСІЙНОЇ ПДГОТОВКИ ОФПЦЕРІВ РАКЕТНО-АРТИЛЕРІЙСЬКОГО ОЗБРОСННЯ}

for Teachers, Post-graduates, Students of Secondary and Higher Educational Institutions]. 302 p. [in Ukrainian].

6. Karavan, Y.V., Sanytska, A.O. \& Tashak, M.S. Netradytsiini formy lektsii $u$ vyschii shkoli [NonConventional Lectures in Higher School]. Available at: http://nauka.zinet.info/15/karavan.php (accessed 23 Apr. 2019). [in Ukrainian].

7. Lutsyk, I. (2009). Interaktyvni seminary yak forma aktyvizatsii navchalno-piznavalnoi diialnosti studentiv vyschykh zakladiv osvity [Interactive Workshop as a Form of Activating Teaching and Learning Activities of Students of Higher Educational Institutions]. Academic Writings of Ternopil Volodymyr Hnatiuk National Pedagogical University. Pedagogy. Vol. 3. pp.125130. Available at: http://nbuv.gov.ua/UJRN/ NZTNPU_ped 2009331 (accessed 29 Apr. 2019). [in Ukrainian].

8. Butnyk, M.A., Holovan,V.H., Drozdov, M.O. \& Roilian, V.O. (2015). Metodychna robota $u$ vyschomu viiskovomu navchalnomu zakladi: navchalno-metodychnyi posibnyk [Methodological Work in Higher Military Educational Institutions: Textbook]. Odesa,198 p. [in Ukrainian].

9. Mokrohuz, O.P. (2009). Multymediina prezentatsiia $\mathrm{v}$ systemi zasobiv navchannia [Multimedia Presentation in the System of Learning
Means]. Computer in School and Family. Vol. 8. pp.21-23. [in Ukrainian].

10. Neschadym, M.I. (2003). Viiskova osvita Ukrainy: istoriia, teoriia, metodolohiia, praktyka: monohrafiia [Military Education of Ukraine: History, Theory, Methodology, Practice: Monograph]. Kyiv, 852 p. [in Ukrainian].

11. Protsenko, O.B. (2015). Innovatsiini lektsii u profesiinii pidhotovtsi mahistriv [Innovational Lectures in Professional Training of Masters]. Pedagogical Process: Theory and Practice. Vol.5-6. pp.63-67. Available at: http://nbuv.gov.ua/UJRN/pptp_2015_56_14 (accessed 26 Apr. 2019). [in Ukrainian].

12. Problemna lektsiia [Problem-Oriented Lecture]. Available at: https://pidruchniki.com/ 10990214/pedagogika/problemna_lektsiya (accessed 22 Apr. 2019). [in Ukrainian].

13. Tolok, I.V. (2013). Pidhotovka viiskovykh fakhivtsiv z vyschoiu osvitoiu: innovatsiini pidkhody [Training of Military Specialists with Higher Education: Innovative Approaches]. Pedagogical Sciences: Theory, History, Innovational Technlogies. No. 6. pp. 259-269. [in Ukrainian].

14. Yahupov, V.V.Netradytsiini seminarski (praktychni) zaniattia. Seminar-dyskusiia [Non-Conventional Seminar (Practical) Sessions. Seminar-Discussion]. Available at: https://eduknigi.com/ped_view.php?id=209 (accessed 29 Apr. 2019). [in Ukrainian].

Стаття надійшла до редакції 10.06.2019

\section{G580801205808

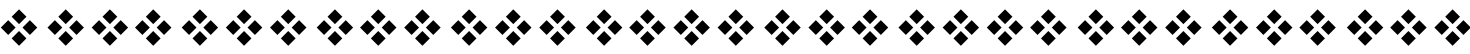

“Dля того, щоб прийти до справжнвого знання, треба спочатку відчути сумніви”.

Apicmoтель

давньогрецький білософ

"Жіщо не буває рано, ніщо не буває пізно. Все буває вчасно".

Конфучиій

давньокитайський бінособб

“Справа усього життя - ие просування вперед”.

Семюел Dжонсон

англійськцй письменник

“Фва основні надбання юдької природи - це розум і міркування”.

Tisymapx

давньогрецький письменник

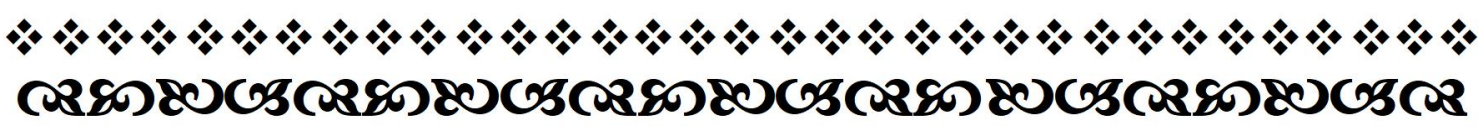

